Terre des hommes (Lausanne)

Delegation for Afghanistan and Pakistan

\title{
WHAT IS ADVOCACY?
}

Hélène Bonvalot

Street working children's project

Danishabad, Board Area

Peshawar
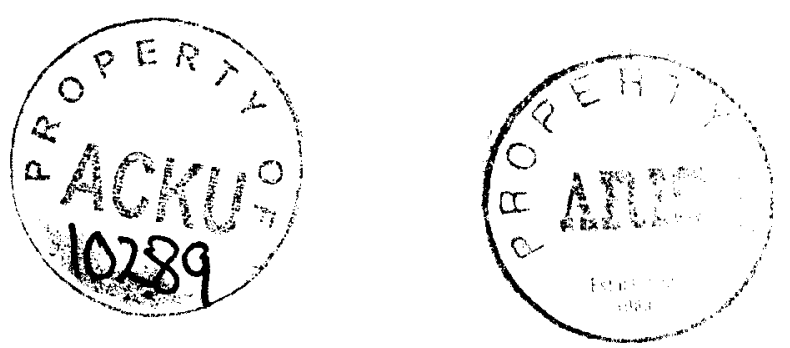

October 17,2002 
What is advocacy?

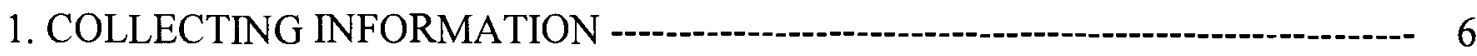

2. WHAT IS THE PURPOSE OF ADVOCACY? ---

3. IMPLEMENTING ADVOCACY - -

1) The Convention on the Rights of the Child (CRC) - 8

2) Advocating at different levels -.-- 9

3) Fields of intervention of advocacy - 10

4) Educational and promotional materials used for advocacy -

4. EVALUATING ADVOCACY -.--

\section{B. ADVOCATING STREET WORKING CHILDREN'S RIGHTS IN PESHAWAR}

Background

Factors of street child labour -

Local concept of child labour -

Advocating street working children's rights -

Street working children's rights -- 13

1. ADVOCATING STREET WORKING CHILDREN'S RIGḦTS ------------------ 13

1) The right to education -...- 14

2) The right to health -

3) The right to recreation and socialization -...-...- 16

4) The right to protection against violence - 17

5) The right to participation -

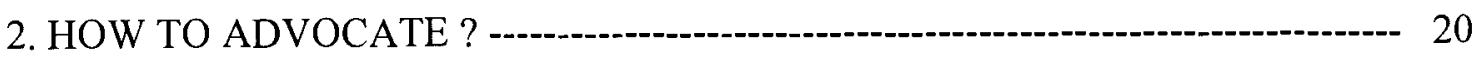

1) Self-advocacy -

2) Advocating among the community - 21

3) Media and networking -- 23 


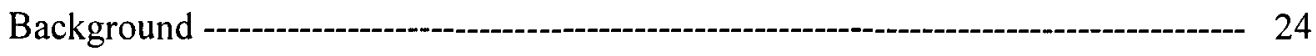

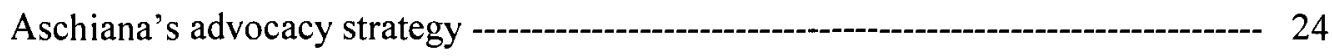

1) Collecting and diffusing information --a--a- 24

2) Awareness-raising --- 24

3) Promoting children's participation --------------------------------------------------- 24

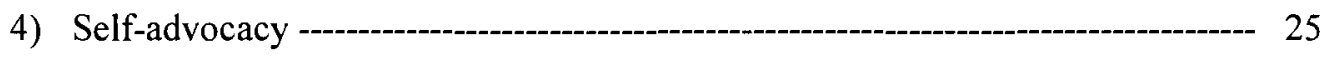

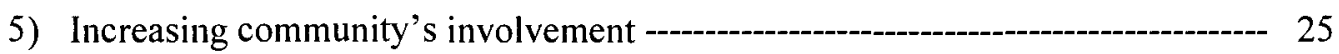

6) Lobbying political authorities --- 26

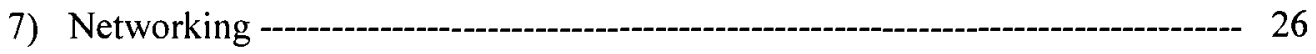

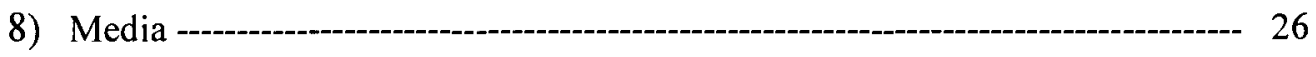

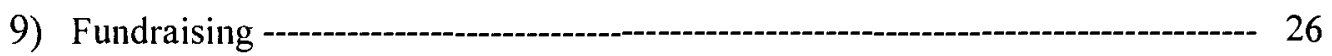

BIBLIOGRAPHY --- 27

APPENDIX --1X 29 
Terre des hommes (Tdh) is a Swiss based NGO working in Afghanistan for the benefit of mothers and children for the past eight years. The Foundation of Terre des hommes (Tdh) is a private, non-profit, international children's movement, free from religious, political or ethnic bias with headquarters in Lausanne, Switzerland. Terre des hommes (Tdh) was founded in 1960 and now works in approximately 40 countries throughout the world to bring direct aid and assistance to abandoned or impoverished children and their families.

This paper has been written from August to October 2002, in the specific context of Peshawar street working children's project and further assessments were made in Kabul with Aschiana street children project, partner of Tdh since 1995. Terre des hommes street children centre was opened in March 2002 in Board Area, an Afghan refugee populated quarter in Peshawar. It was the first project Terre des hommes implemented in Pakistan while the Swiss Foundation has been present in Afghanistan since 1995. The existence of the project was justified by the tight links between Pakistan's North West Frontier Province (NWFP) and Afghanistan due to refugee movements and ethnic cross-border relationships among Pashtun populations.

From the beginning, Peshawar street working children's project has been considered as an opportunity to fully implement Terre des hommes' strategy regarding children in street situations, on a small scale and in an experimental way. Advocacy, networking and lobbying have been clearly included in Terre des hommes' intervention strategy and it was worth identifying how they could materialise.

As a first step, general information on advocacy commitments has been requested from Terre des hommes' delegations and other agencies involved with street working children in Pakistan and other countries. It was found that few organisations have defined a clear advocacy strategy, given that few agencies have a clear idea of the concept of 'advocacy'. Some Terre des hommes' delegations running street children projects were not able to provide sufficient information. Most of them answered that they had done nothing or very little to promote children's rights. Others did not even answer the request. It appeared that also Terre des hommes has a deficiency regarding one of its principal mandates, i.e. promoting and defending children's rights in the framework of the CRC.

The main objective of this paper was to define more precisely the concept of advocacy and to identify how to advocate street working children's rights in accordance with local potentialities and constraints. After analysing information from different agencies, concrete suggestions have been made that could apply in Peshawar and possibly in Aschiana in Kabul. The findings are not limited to Terre des hommes' involvement in Pakistan and Afghanistan. They might benefit to the overall Terre des hommes' delegations and other agencies committed in favour of children's rights.

Giving a clear and succinct definition of advocacy has proved to be quite difficult given that any advocacy step involves decision-makers and opinion-designers at several levels. The objectives and actors of an advocacy strategy vary according to the content and extent of the matter advocated for/against. Advocacy is a large concept that needs adapting and shaping in accordance with the specific issue of street working children. Guidelines have been identified throughout this paper and might be useful for whoever means to advocate street children's rights. 


\section{A. DEFINING THE CONCEPT OF ADVOCACY}

\section{WHAT IS ADVOCACY?}

Most of the NGOs appreciate the benefits of having clear advocacy strategies but very few have them. The sort of issues NGOs advocate about range from general principles of inclusion and participation in decision-making, through macro-issues such as reform of the World Trade Organisation, to specific issues such as education, debt or child labour.

Most NGOs see the quality of the relationship between their programs and advocacy work as crucial to their legitimacy and effectiveness. Micro-macro links are very important for the legitimacy and effectiveness of advocacy. However, NGOs lack formal or substantive mechanisms of accountability to their intended beneficiaries for their advocacy work.

There are numerous definitions of advocacy, every organisation having developed its own understanding and strategy to (non) implement advocacy. Terre des hommes defines advocacy as following: "Liaising with and lobbying subscribers and policy makers, including the use of public events and media coverage, regarding the violation of rights encountered by street children and appropriate measures to counter them. Means: Situation analysis, network, child participation through street contact, children's organisations, individual follow-up'." Other agencies have adopted a quite different definition according to their field of intervention and the stakeholders involved in the issues they are dealing with. But mostly NGOs tend to focus on advocating at government level rather than at community or children level.

In street children projects, advocacy aims at increasing the understanding of the general public and of policy-makers of the needs of street children. Advocacy is implemented to promote action from lawmakers, law-enforcers and providers of social services, e.g. to improve the situation of street children. Advocacy is developed both at community level, to raise awareness within local community of important issues affecting their children, or at national/international level, by launching campaigning projects.

The issue of street working children is advocated to:

$>$ Enable street children to voice their concerns,

$>$ Build support for that issue,

$>$ Influence others to support it,

$>$ Promote governmental action and the implementation of adequate policies,

$>$ Try to influence or change legislation that affects it,

Bring about attitudinal change within local community,

Make children aware of their rights and empower them.

Advocacy is linked to empowerment. Emphasis must be put on the strengths and capacities of the children rather than on their vulnerability, in order to preserve the dignity of street children. Advocating children's rights cannot be managed exclusively by adults. Children know better than anyone else what they need and what is good for them. Adults are the facilitators who enable children to express themselves and get heard within society.

\footnotetext{
${ }^{1}$ Daniel STOECKLIN, Children in Street Situations - Terre des Hontmes Strategy, Fondation Terre des Hommes, Lausanne, 15 février 2002
} 


\section{COLLECTING INFORMATION}

Before starting any advocacy initiative, it is essential to pinpoint the cause or issue an organisation is advocating for, i.e. what they will work to support, and decide what they want to be the outcome of their advocacy efforts, i.e. what concrete result they want to achieve. It is also essential to identify who an advocacy campaign is targeting, i.e. who the decision-makers are, who is really holding the power.

It is essential to decide upon an approach to advocacy. There are three different approaches to advocacy:

$>$ Advocacy for those affected by a situation, i.e. street working children, done by NGOs or professionals in place of children,

$>$ Advocacy with those affected by a situation, when professionals and NGOs accompany children and local community,

> Advocacy by those affected by a situation, i.e. self-advocacy, which is often the most sustainable way of advocating.

The profile of people advocating depends on the type of approach that has been selected. To strengthen and increase the impact of his/her argumentation, the advocate must collect reliable information and develop a solid knowledge on the issue advocated for/against so as to be able to respond and thwart his/her opponents. Children who are self-advocating should be in position to present their daily reality and explain the difficulties they are facing.

Successful advocacy thus relies on well-researched data and reliable information, and on personal testimonies to persuade its audience. Those who are undecided on an issue, or even opposed, are frequently convinced by statistics that support an advocacy position. Advocacy must be based on quality information about street working children, including real and verifiable facts and statistics, never on suppositions, newspaper reports or hearsays. Collecting information must be based on transparency.

Broad information is to be collected, regarding:

> The population as a whole (economic climate; (un)employment; family structures; housing; homelessness),

$>$ The community from which street working children come (special features),

$>$ The child population (health, education, labour, level of awareness),

$>$ Legislation affecting children,

$>$ Government involvement in child welfare and child protection,

$>$ The children and community's level of awareness about children's rights.

Broad information can be found in:

$>$ Government departments (country reports),

$>$ Local police (local law and justice),

$>$ Local schools, 
$>$ Local NGOs and private welfare groups,

$>$ International NGOs (alternative reports to the Committee of the Rights of the Child),

$>$ International agencies,

$>$ Medias (newspapers, TV),

$>$ Universities,

$>$ Libraries.

Collecting information helps to properly identify the issue advocated against/for. The problem is not to be confounded with the symptom. Street child labour is the symptom, the visible manifestation of deeper problems rooted within society, e.g. refugee movements, economic poverty, unemployment, lack of education and health facilities. A combination of political, economic or social problems triggers off a crisis of social integration and leads to street working children's social exclusion.

\section{WHAT IS THE PURPOSE OF ADVOCACY?}

The objective of any advocacy strategy is to promote social integration and empowerment among the child population and the local community. Advocacy is implemented to enable those without power to gain access to it, and help those who feel powerless to see what power they already have. Advocating means being a voice for the voiceless and enabling the voiceless to find their own voice.

\section{Advocacy aims at:}

Promoting children's participation, encouraging children to voice their perceptions and to defend their rights, i.e. self-advocacy,

$>$ Developing children's skills and abilities acquired in/off the street (sharing, solidarity, critical mind) to redirect them in socially accepted directions,

Raising general public awareness on the advocated issue,

$>$ Promoting capacity-building so that the poor and disadvantaged will become agents of change themselves,

$>$ Promoting governmental policies and effective action,

$>$ Networking, i.e. sharing information and collaborating with police officers, local authorities and other agencies involved with children in the same area. 


\section{IMPLEMENTING ADVOCACY}

Any advocacy strategy promoting children's rights must be implemented within the frame of the Convention on the rights of the child $(\mathrm{CRC})$. Children's rights advocated for concern all children, not only child laborers. Street working children are youngsters with their own personality, needs and wishes and mustn't be considered a homogeneous victimized group.

\section{1) The Convention on the Rights of the Child (CRC)}

Advocating children's rights is based on the four general principles governing the 54 articles of the CRC.

$>$ Non-discrimination (article 2): All rights apply to all children without exception. It is the State's obligation to protect children from any kind of discrimination - through legislation, institutionalised attitudes, media and government action or inaction - and to take positive action to promote their rights. Non-discrimination is relevant to all CRC articles.

$>$ Best interests of the child (article 3): All actions concerning the child shall be in his/her best interests. Boys and girls should be given primary consideration when resources are mobilised and allocated.

$>$ The child's rights to survival and development (article 6): Every child has the right to life. The State has an obligation to ensure the child's survival and development. Child development is a holistic concept, including physical, cognitive, emotional, social, cultural and spiritual development, and demanding consideration of the whole child.

$>$ Participation (article 12): Girls and boys have the right to be involved in decisions affecting them. Children's views must be sought and considered in all matters that affect their lives. In order to make decision, children have the right to relevant information provided in form they can understand. The right to participation recognises the child as an active and contributing participant in the society.

The gender perspective cuts across all children's rights and should be addressed when implementing any article of the CRC. Gender refers to social and cultural interpretations of biological sex, i.e. what is considered to be 'female' and 'male' in a given cultural setting and the roles and relations between both sexes. Differences in biological sex are often used to explain and justify inequalities. Power relationships subordinate females in a lower status than males. Gender discrimination against child girls is to be advocated through knowledge, empowerment and through addressing negative attitudes and practices. 


\section{2) Advocating at different levels}

Advocacy takes place at many levels, wherever there is a relationship between decision-makers and people affected by their decisions. Decisions made at one level affect people at another level. Advocacy is necessary at all levels for lasting change. Any advocacy strategy focusing on one single level will have at best a short-term isolated impact and will not seriously tackle the root problem.

1. Self-advocacy, by the children themselves, through educational sessions, social animations and discussions on the CRC. Adults must let children speak and express their own concerns with their own words. Children must be involved in defining their problems and expressing their opinion. Children's organisations have been established throughout the world by children themselves and/or with the guidance of adults. Within these organisations, the whole process is controlled by the children. They identify themselves issues of concern and means to address them. The role of adults is to facilitate, not lead.

2. At family level, as families provide material and emotional support to the children. Advocating the rights of the children means promoting a attitudinal change within the society, bringing about changes that will improve children's lives.

3. In local community, providing information and promoting debate and reflection. Successful advocacy relies on the community's support, approval and commitment to help. The community's involvement within the project might occur as followed: the project might share its services with the community while children might get access to community facilities. Local businesses might also provide financial resources (sponsorship, donations...) to contribute to the maintenance and improvement of the project.

4. With local authorities, requesting financial or material support. Collaboration will be facilitated if the stakeholders maintain a positive relationship with the authorities. Diffusing regular information can help to raise awareness and educate public and policy-makers.

5. At national level, lobbying government authorities and influencing the content and implementation of national health and education policies.

6. At international level, to draw the attention of States and international organisations on global issues affecting or concerning both rich and poor countries. 


\section{3) Fields of intervention of advocacy}

$>$ Providing services

Advocacy aims at offering street working children vital protection against the damage of street life. Establishing a project means that existing services are not meeting the needs of the children. It is a form of criticism towards the State.

$>$ Gaining attention and increasing understanding

Raising awareness of the situation of street working children, helping people to understand their special needs, encouraging action to be taken.

$>$ Promoting children's self advocacy

Enabling children to speak out and express their opinion, creating opportunities for that opinion to be taken into account, making children aware of their rights and understand how those rights are violated.

$>$ Working with the media (local and national newspapers, radio and TV)

All forms of media can be useful to convey your message if properly use them. Publications or leaflets can be published and distributed locally, nationally or intemationally. Anyone advocating needs to ask what the media is and if she/he should use it - if yes, then how ? Before using the media, it is essential to decide what you want to say and how you want to say it. You need to ask for the approval of the children so as to respect their privacy and intimacy. Media can be used to raise money for the advocated cause. It is a good opportunity to request donations from the general public once people have got informed.

Denouncing the State's response to street children

Street child labor is a manifestation of the State's failure in delivering services and implementing social policies. It is advised to use tact and diplomacy to encourage the State to better consider the issue of street working children. Shaming the Government for its lack of action or its repressive attitude will lead to the institution of bad relationships between the State and the NGOs and will undermine any advocacy action with the authorities.

$>$ Promoting State provision for street working children

It is essential to organize private or public meetings with representatives from government departments to promote State provision for street children and transform apparent commitments into practical government action.

$>$ Making clear demands to the State (e.g. provision of education/health services and financial/institutional support for NGO, end of physical abuse by the police....)

$>$ Establishing partnerships

A united voice might have more impact on Government rather than individual voices. Partnerships can develop through a consortium or a task force. They aim at sharing information, resources, experiences and expertise.

\section{$>$ Networking}

Not every organization should try to deal with all children. It would lead to competition, duplication of efforts and waste of human/financial resources. 


\section{4) Educational and promotional materials used for advocacy}

Advocating means diffusing a message that must be shaped or developed clearly depending on who you want to reach with your message. It is essential to use appropriate language, images, personal stories, that are culturally acceptable, clear and simple. What materials you use will depend on your audience and objective.

Fast cards: they are commonly used for Parliamentarians (easy to put in their pocket/handbag and helps them look informed on the issue),

$>$ Petitions: e.g. on an interactive website, they help make people feeling like they are taking some action,

Corporate brochures: they present a short and straightforward explanation of your work,

$>$ Annual reports: they provide more substantial details (on-going debate about the target audience of our annual report - donors, general public, media).

Advocacy materials mainly include pamphlets, flyers, newsletters, annual reports, position papers, fact sheets (fact cards - small, convenient size), canvassing, petitions (websites, postcards).

\section{EVALUATING ADVOCACY}

Monitoring and evaluating advocacy is not an easy task. It is difficult to identify and measure some indicators that could properly point out the progress made in the short-term at government, community or personal level. It is generally considered that social behavioral change is a good indicator for monitoring and evaluating advocacy. Nevertheless social change is detectable in the long-term and any advocacy strategy requires short-term indicators to measure its effectiveness and reliance and reorientate if it is not adequate.

Regular follow-up and monitoring mechanisms are to be implemented. Documentation of all process, failures, successes and learning for future reference should be recorded and kept. Any achievement should be highlighted and publicized to motivate people concerned by the advocated issue. The fulfillment of political commitments should be monitored on a regular basis, to put pressure on government and ensure that commitments are developed into actions. At lower levels, the active participation and motivation of children and local community should be observed whenever a collective event (training, rally, seminar...) takes place. 


\section{B. ADVOCATING STREET WORKING CHILDREN'S RIGHTS IN PESHAWAR}

\section{Background}

Tdh street working children centre was opened in March 2002. 120 street working children from the neighbourhood attend the centre in two shifts - 60 in the morning and 60 in the afternoon - and are provided with recreational activities, non-formal education, social abilities, health services and education, personal hygiene facilities and nutritional support. The local staff includes one project coordinator, two teachers, two social animators, one street animator, two social workers, one medical doctor, one psychologist, one cook and two guardians.

\section{Factors of street child labour}

Danishabad is a poor neighbourhood in Peshawar where a large proportion of the population consists of Afghan refugee families living out of refugee camps. Adults' unemployment or sub-employment is a strong factor that influences parents to send their children to work to increase the family's incomes. Most of the children attending Tdh centre are from Afghan refugee families and have faced a linguistic barrier to enter governmental public schools. They speak Pashto or Dari and cannot attend a class taught in Urdu. Many families also feel disillusion towards school and do not regard education as a means to improve their children's livelihood. They would prefer their sons to learn a trade working as an apprentice, while their daughters mostly stay at home and help with the housework, collecting firewood in the surround area and bringing drinking water from the well or shops.

\section{Local concept of child labour}

Most families consider child labour as part of the process of growing up and preparing for adulthood. Child labour is a socially accepted reality and children, as any family members, play a role in the economic survival of the family. Many families think that skill development (learning a trade) is more important than formal education and prefer sending their children to work rather than to school.

Child labour consists on a full-time work at a very young age, with low/no wages, a limited access to education and an excessive physical, social or psychological pressure on the child. Many children fulfil the obligation to go to work as a means to valuate their obedience to their parents and be considered a good son/daughter. Child labourers get very little gain for themselves and suffer an accelerated health deterioration, a lack of self-confidence and low self-esteem, physical or sexual abuse, official and domestic violence, drug abuse.

\section{Advocating street working children's rights}

Most of the work done by children is "invisible" as they work within their families, are self-employed or work in the informal sector activities. Little or no governmental legislation is enforced or enforceable in most child labour cases. Advocacy does not only consist in lobbying the authorities but also in awarenessraising among local community and networking at a local/national/international levels.

Advocating to defend and promote street working children's rights is not only justified by legal or ethical reasons. Social and economic purposes must be the other two pillars of any advocacy approach. Reducing the worst forms of child labour and developing a model of educational and management practices for street working children is a means to invest in improving society and reducing relative deprivation while investing in the future workforce and promoting economic development.

Street working children have least consistent access to essential services such as education and health. Any advocacy strategy must take into account the necessity for street working children to be provided with educational and social skills while working in safe and respectful conditions that are adequate to their physical, mental and emotional development. 
Any street working children project must rely on a rights-based approach rather than a needs-based approach. Basic services delivering must be integrated into an holistic family-based and communityowned approach. Awareness is to create with street working children themselves, their families, the community, the employers and local authorities through participatory mechanisms and networking.

\section{Street working children's rights}

The framework for advocacy is the Convention on the Rights of the Child (CRC) that was enacted on November $20^{\text {th }}, 1989$, and ratified by Pakistan in 1990. Nevertheless the CRC is a theoretical and universal paper that needs adapting to every specific context according to local realities and cultural values.

To properly advocate street working children's rights it is required to have a correct perception - free of any misjudgement or misperception - of who is a street working child. When we think about 'street working children', we tend to focus more on the 'street' and the 'work' - i.e. victims of civil, political and economic rights abuse - rather than on the complexity of every 'child' as an individual with his/her own needs and demands.

Street working children are not a homogeneous group. We need to understand each child's situation and empower them through social, recreational and educational activities to make choices relevant to their lives $^{2}$. Street working children, like all children, are not to be considered as victims but as actors endowed with a great potential who can fully participate in their own development and that of their peers and wider community.

\section{ADVOCATING STREET WORKING CHILDREN'S RIGHTS}

The Convention on the Rights of the Child (CRC) promotes all rights children should enjoy in their daily lives. The main rights street working children should enjoy are the following:

$>$ Access to basic education and vocational training, adapted to their working responsibilities,

Access to health education and medical care,

$>$ Time for recreation, relaxation and leisure,

$>$ Working conditions suitable to their physical, mental and emotional development,

$>$ Protection from any kind of official or domestic violence,

$>$ Participation in all matters affecting their lives.

\footnotetext{
${ }^{2}$ Daniel STOECKLIN, Children in Street Situations - Terre des Hommes Strategy, Fondation Terre des Hommes, Lausanne, 15 février 2002
} 


\section{1) The right to education}

Street working children need specially formulated, personalised, mediated programmes adapted and appropriate to their needs and circumstances, both in terms of content and teaching methodology. Street working children are excluded from formal education system and need to get access to non-formal education.

Non-traditional education relies on creative teaching methods, aiming at providing children with the life skills they need on the streets - i.e. hygiene, self-confidence, social problem solving skills, non-violent conflict resolution, communication, trauma therapy -, apart from basic literacy and numeracy.

Street working children must be provided with cognitive knowledge to develop their capacity for reflection and better adapt to the complexities of street and working life.

Child labour perpetuates the cycle of intergenerational poverty as individuals with a limited education will find it relatively harder to enter the adult labour market. They will be at disadvantage compared to higheducated/skilled people and may have to do the most precarious and lowest paid activities.

\section{Suggestions:}

> Children's empowerment requires non-traditional teaching methods. Games are used to develop motoric capacities and stimulate thinking. Activities such as mediation games, puzzles, crosswords, ..., make children share rules and limits, the same they shall face and respect in social relationships.

Education activities should start from the children's own experience. Language learning should start from the language of the streets and geography from the local geography and the child's own experience as a refugee and encompass physical and social geography.

$>$ Subjects must be chosen and designed according to the children's needs and interests. Most of the children attending Tdh centre are Afghan and should be provided with geographical, historical, human knowledge about their home country to know more if they get to repatriate.

Further contacts might be taken with the children's employers to develop apprenticeship schemes and provide working children with vocational skills in order to increase their access to better economic opportunities. 


\section{2) The right to health}

Street working children's physical health is challenged both by questionable personal hygiene and hazardous health conditions at work. Many street working children are undertaken in conditions of poor hygiene, with minimal security and protection of employment, and no social security. There is often no work agreement, leading to frequent abuses and in a high - but usually unrecorded - level of accidents and illness. Self-employed children are mainly unaware of the risks and dangers they face in the streets. They do not often wear sandals while standing in garbage and eat rotten food found in the bins. They easily cut and wound themselves and are liable to skin or intestinal infections.

Personal hygiene is tackled in Tdh centre. Children take a daily shower and are provided with towel, soap, toothbrush, toothpaste... The doctor provides them with health education to make them know about their body and how to protect it against external and internal aggressions.

Street working children's mental health is threatened by high rates of stress and anxiety, affecting children's mental and emotional development. While their earnings may constitute only a small proportion of the family income, parents may resort to beating and physical abuse when children fail to work long enough hours or bring back the anticipated amount of money. Verbal insults can also lead to low selfesteem and a lack of self confidence among children.

\section{Suggestions:}

Health education can develop through creative media such as songs, games, crosswords, to get children interested and active participants.

Modules on personal hygiene have been implemented by other organisations according to local circumstances and facilities. Children kept and updated a chart at home to evaluate themselves. They appointed when they had brushed their teeth, when they had washed their hands before eating, .... and were given a prize when they had reached agreed goals. Siblings and cousins encouraged and stimulated each other. Such modules could be adapted and implemented in Danishabad. What concrete and achievable goals could be set in a neighbourhood where there is no drinking water nor health facilities?

$>$ A monthly chart should be updated by Tdh medical doctor, presenting the five main diseases affecting children and a general overview of the health status of the children. This could be sent to any agency dealing with childhood or health and to local authorities to help design a suitable health policy.

$>$ The whole staff should help the psychologist to identify timid and introvert children, those who lack self-esteem and self-confidence and those who do not feel at ease in social circles. Individual activities could then be contemplated.

General cleanliness of Tdh centre should be partly taken in charge by the children themselves. They could organise in teams, each team being responsible for a specific task every day, e.g. one team would help to distribute the food, another one would help to collect and wash the dishes, a third one would sweep the classrooms, and the latter would make sure that towels have been properly hanged up. Male teams and female teams should be formed to avoid any gender clashes. The most efficient team of the week might be awarded, e.g. with a picture of themselves signed by the project coordinator. This would develop children's motivation and diminish the risk of gender discrimination. Taking responsibilities within the centre would enable children to develop a feeling of ownership and importance as they become actors in their own development. 


\section{3) The right to recreation and socialization}

At an individual level, street working children have little/no time available for recreation nor for socialization within the family and with peers at school. Hours spent at work affect children's access to and availability for recreation ${ }^{3}$.

Street working children are 'children' before being 'street laborers' and they must get access to recreation a few hours a day. Tdh social animators provide them with social abilities through games and playful activities including cut-and-paste, painting, drama, theatre, music... Children must respect rules and limits and adopt a respectful attitude towards each other.

In terms of construction of identity, street working children's families are involved in cultural patterns that affirm child labor. They perceive as normal and valid that children should work from an early age in order to help the family and consider that children who do not work are lazy. Hence street working children are likely to see themselves primarily as producers and will grow up without discerning their own needs and rights as children.

It is essential to provide children with time and desire to play. Games can be a useful means to acquire social and life skills needed by street working children in their daily life. It is the way to get closer to the others and open up as a social member. Each child gets to know better about him/herself and is aware of his/her own situation within a social framework.

\section{Suggestions:}

Social activities should be adapted to the children's needs and demands as formulated by themselves during regular consultations. A coordinator for social animations has been appointed, who will be responsible for deciding jointly with social animators and children themselves upon both the contents and the progress of recreational activities.

$>$ Children should regularly bring back home their paintings, drawings, ..., to show their families their artistic production and be motivated to further develop their creative talents. It is essential to get families informed about what their children are doing within the centre to maintain and reinforce links between $\mathrm{Tdh}$ centre and the community.

Street recreational activities should be developed and enhanced, including not only sport activities but also discussions, debates, competitions, theatre... We could further think about implementing street education activities. Street activities depend on street animators' ability to reach and raise interest among children who are not attending the centre. Street contacts could facilitate further selections if some children currently attending the centre are to leave for any reason (repatriation to Afghanistan, integration to formal education system...).

\footnotetext{
${ }^{3}$ Terre des homes - Aschiana. Needs assessment of children working in the streets of Kabul, July 2002.
} 


\section{4) The right to protection against violence}

High levels of general societal violence are linked to socio-economic circumstances, frustration at high levels of poverty, political instability and ethnic, racial or social tension. A general background of conflict and the lack of positive perspective can both contribute to the increase in numbers of street working children (through displacement and the creation of orphans), and in the increased levels of violence against street children. Street children can even be seen as the causes of these wider societal problems, being scape-goated for crime levels due to their visibility in street crime. Where countries are experiencing widespread conflict and high levels of violence, street children inevitably sink even lower down a government's list of political priorities.

Street working children are doubly vulnerable to violence. On one hand, they are more likely to come into contact with the police because of their existence at the margins of society and the nature of their 'survival activities' (begging, scavenging, petty theft...). One the other hand, they are more vulnerable to abuses within the system because of their lack of current contact with responsible adults to safeguard their rights on the streets.

Official violence - perpetrated by State officials (police and military) - against children on the streets is perhaps the most obvious and the most 'traditional' form of violence associated with children working/living in the streets. Street children are dehumanised. Not only are street children an embarrassing, visible reminder of a society's failure to provide for and protect its most vulnerable children, but they are also considered a threat to that very society by the way in which they live. Dehumanisation is the most dangerous threat posed to vulnerable children in that it absolves people, especially the authorities, of the obligation to accord them their human rights.

Children attending Tdh centre are particularly at risk of abuses perpetrated by the police because of their refugee nature. Most of them were not registered when they were born and do not have any identity documentation. Pakistani policemen generally ask Afghan street working children for any identity document - knowing perfectly that they do not have - and might send them to jail if they cannot justify about their presence in Pakistan. They inflict bad treatments and physical beatings on street working children as a means to affirm their official power.

Domestic violence is commonly experienced by street working children. Economic pressures contribute to violence within the family. Common causes for beatings are because a child has not brought enough money from begging or petty trading to meet the family's (usually father) expectations. The pressures of economic poverty include economic stress and lack of time and energy to devote to children's upbringing. They are generally combined with lack of awareness of positive, non-violent parenting skills and societal acceptance of violence. Violent socialization patterns and poor communication skills experienced in the home, including gender socialization (patterns of violence against women), can be absorbed by children and perpetuated in the streets.

Violence within the home is experienced by the children both as direct victim-survivors of violence, and as witnesses of violence against another family member (usually the child mother). Witnessing domestic violence is in itself a form of abuse.

The effects of domestic violence can include: insecurity and low self-esteem, behavioural and developmental problems and under-achievement, fear and an inability to trust, problems with social competence and peer relationships, resentment, guilt, self-blame, aggression and tantrums, introversion and withdrawal, normalization of violence as a form of communication or in response to conflict resolution which may, in turn, lead to a cycle of abuse. These lasting effects are common to all children having experienced domestic violence, and are not specific to street working children.

Violent socialization patterns experienced at home can manifest themselves in violence which is both necessary for self-protection on the streets, and which - in the absence of non-violent communication skills - is considered a normal recourse to resolving dispute. Certain types of drugs can induce violent behaviour per se or can lead to violent behaviour as a consequence of the need to obtain further drugs in order to satisfy addiction. 
Sexual abuse is an issue Pakistani society has always been reluctant to address. Although it is unreported, child sexual abuse is considered to be fairly widespread in Pakistan. Both girls and boys are at risk of being sexually abused. One of the most usual forms of abuse is incest particularly among the girls.

In majority of child sexual abuse cases the abuser is someone from the family or its immediate social circle. It is someone the child is personally acquainted with, somebody the child has come to trust and look up to. The greater the duration and frequency of incest, the more harmful its effects. Closer the relationship between the abuser and the victim, the greater the damage to the child.

Most of the time, parents tend to believe that a relative or a friend cannot harm and do not give their children the opportunity to say they were sexually abused. Since most of the children are unable to discuss the issue with their parents or with another adult, they continue to be abused. Exposing such incidents can be extremely unsettling and traumatic for the people concerned. The child often feels that it is due to his/her fault that the abuse is taking place.

Street-living/working girls are particularly vulnerable to sexual violence. They suffer a perceived loss of rights over their bodies - which is yet another manifestation of 'otherness' or dehumanisation. This is compounded by gender stereotypes in male-dominated cultures which define these girls as not 'nice girls'. Street working girls' 'psychological death' finds expression in violent behaviour, depression, withdrawal and self-mutilation.

\section{Suggestions:}

$>$ Violence, specifically domestic violence, is not an easy issue to discuss and deal with. It is important to address the issue of domestic violence with the families without relying on the potentially counter-productive stigma of labelling people 'bad parents'. It is essential to work with the families and help the parents identify how they could help their children to develop without mistreating them. Modules implemented by the psychologist should be based on the father's own experience as point of reference. We can collectively or individually discuss with the parents what they would have liked from their parents, how they would like to be regarded by their own children. Discussion must be hold in the light of their cultural values and religious beliefs.

$>$ Effects of physical/sexual abuse can vary enormously depending on a child's age, gender, exact experience, personality and external support factors. An individual approach and analysis of each child's particular situation is therefore needed, both in terms of research and intervention. An individual approach by the psychologist shall reveal children's resilience. Children are not only 'passive victims'. They are individuals with their own strengths and coping capacities.

$>$ As children tend to reproduce violent patterns they suffer or witness at home and in the streets, it is essential for the psychologist to implement non-violent conflict resolution education. Violent attitudes should not occur within the centre as children should learn how to peacefully manage and solve their conflicts with the others.

it While sexual abuse is taking place, the child always gives some indication. Staff members particularly the psychologist - must pay attention to children's abnormal behaviours to identify sexually abused children and support them as soon as possible. It is considered that many abusers have been found to be abused themselves when they were children. It is essential to help young victims partly overcome the trauma they suffered and develop as well-balanced adults so as to break the circle of abused children becoming abuser adults. Preventive activities might also been implemented, providing children with information and advice on what attitude they should accept or not accept from surrounding adults.

$>$ Preventative measures must remember the role of families, communities and children in protecting themselves. Structural and institutional change might be achieved if all families are reached by any general public awareness campaign/event or non-violent conflict resolution education. We must make sure that the means of dissemination of information and sensitisation is appropriate (taking into account illiteracy, local languages, religious beliefs...). 


\section{5) The right to participation}

All children have the right to participate in all matters affecting their lives. Children have long been considered as passive members within society. Each child should be seen as an active contributor in local community, with his/her own opinion and needs to be fulfilled.

Street working children should fully enjoy the rights affirmed in the CRC, including the right to participation (article 12), while being considered as active economic contributors within society. Their double status - as children and as labourers - should provide them with a strengthened right to participate in all decisions affecting their existence

Street working children should be given the opportunity to express themselves and give their point of view regarding daily matters. They should be enabled to find their own voice and defend their rights whenever these are denied. Implementing the right to participation means empowering children so that they can advocate themselves to defend and promote their rights.

The right to participation needs accompanying with the right to information. Children cannot reasonably participate in important decisions affecting their lives if they are not provided with reliable information adapted to their age and knowledge. Children must get informed about their rights, the society and the country they are living in, the dangers and opportunities of daily life...

\section{Suggestions:}

$>$ Children should be consulted on a weekly/monthly basis within the centre to identify the activities they would like to be provided, according to their needs and wishes. Consultations with the children should take place before organising any special event - such as a rally or an excursion to get the children's points of view and their wishes.

$>$ Children should fully participate in the maintenance and daily monitoring of the centre. Male and female teams would be in charge of specific tasks. Each team could appoint its own representative who would be responsible for informing the staff if any suggestion or problem.

$>$ Children must be provided with information which is adequate to their age, language and knowledge. It is essential to continue to implement activities such as health education, mines awareness, non-violent conflict resolution, environmental awareness, ..., to be in capacity to discuss important issues with children and enable them to take their own decisions.

Debates and discussions should be organised on general topics or whenever an important event occurs in Pakistan, Afghanistan or in other countries, directly or indirectly affecting their present or future lives (e.g. Afghan refugee flows to Pakistan). The information should be provided and discussed in a simplified way, using methods such as brainstorming or drawing, to enable children to better analyse and understand the information provided in their homes. 


\section{HOW TO ADVOCATE?}

\section{1) Self-advocacy}

Self-advocacy is not easy to be conceptualised nor implemented. Most children are used to being dominated and need to develop self-confidence and self-esteem to be in capacity to identify their own needs and aspirations. Recreational and educational activities aim at developing the children's curiosity and capacity of reflection to enable them to make responsible choices regarding their lives. Empowerment is at the core of any project involving street working children.

\section{Suggestions:}

Children's knowledge and comprehension of their rights and duties could be developed through regular workshops tackling issues such as the family, nature, health, personal hygiene, labour... Simple but clear subjects should be identified and discussed with the children to raise their curiosity about their social environment and lead to a better understanding of their situation as children within a specific community. A few children participated to a workshop on CRC organised by HRMDC in September 2002. Weekly workshops should be organised on that participative model according to the age and background of each group of children.

Children's sense of ownership and responsibility could be developed through the implementation of male and female teams within the centre. Each team would be in charge of a clearly defined daily task, e.g. distributing the food, washing the dishes, cleaning the classrooms... It is relevant to increase the children's participation and involvement within the centre to make them feel responsible and thus contribute to their empowerment.

Children could self-advocate their rights within the community through outside activities such as street theatre and wall-paintings. On the occasion of $13^{\text {th }}$ anniversary of the CRC on November $20^{\text {th }}, 2002$, children might present a short drama written and staged by themselves. Children from the whole neighbourhood - not only children attending Tdh centre - could, jointly with street animators, design wall-paintings on topics discussed and selected altogether. 


\section{2) Advocating among the community}

The local community is very traditional and conservative and it is essential to be very careful while advocating for street working children's rights. Advocacy must be thought and implemented according to religious beliefs and cultural values. Involving the community within Tdh street working children's centre is a good way - maybe the best way - to raise awareness about the critical situation of street child labourers in Danishabad. It was observed by social workers that most of the parents have felt satisfied and relieved since Tdh opened its centre in March 2002. The centre must develop and improve its activities and service delivering according to the community's comments and feelings. It is the only way to get the centre fully integrated within the neighbourhood and induce progressive attitudinal change.

Children's parents have been informed and involved into the project from the beginning. A family meeting was held in June 2002 to present Tdh centre's activities and objectives. Social workers regularly visit the families to get their approval and know more about each child's domestic situation.

\section{Suggestions:}

$>$ That would be good to further involve children's families in Tdh centre's activities. Staff turn-over is quite high and it is required to train and involve volunteers from the children's families (older brothers sisters, mothers...) to help implementing inside and outside activities. Volunteers could come to the centre on a weekly basis to strengthen the links with the community and bring new ideas.

$>$ Regular meetings should be held - e.g. twice a year - to get parents informed about the activities and services provided to their children and redirect Tdh's objectives and strategy according to the families' observations, needs and wishes.

$>$ Many families have asked for a second or third child attending the centre. According to Tdh criteria, maximum two children per family - one female and one male - can attend the centre. We might think about how we could punctually involve 'our' children's young siblings in some activities to raise awareness and curiosity among them and help developing the life skills they may need later on. Most of these younger children might become street working children like their eldest and we must think about any prevention strategy to implement with their parents and the children themselves. E.g. we could invite them from time to time to participate to a specific activity within or outside the centre. It could be a game, a drawing/sport competition, a rally...

$>$ It would be important to involve the children's families to celebrate the $13^{\text {th }}$ anniversary of the Convention on the Rights of the Child (CRC) on November $20^{\text {th }}, 2002$. We might organise a general public meeting outside the centre in Danishabad and invite the whole community to celebrate the event. Children could intervene and be regarded as active participants in the development of their own community. The whole community would be invited to a big mechouis. As it is Ramadan time the event would take place at night. 
Local community has also been informed and involved in the project. A community meeting was held in September 2002, gathering teachers, representatives of community-based organisations and other community leaders from the neighbourhood. Many participants had misperceptions regarding Tdh's project and objectives and sensitive issues such as non-schooling, child labour and religious education were openly discussed. It is essential to maintain and strengthen the links with the community.

\section{Suggestions:}

$>$ The whole community may be invited to the celebration of the CRC on November $20^{\text {th }}, 2002$. It might be relevant to think about how we could involve them in the preparation and realisation of the rally.

$>$ Religious leaders were visited and informed when Tdh opened its centre in March 2002. A meeting might be organised to correct misperceptions and get fully accepted within the neighbourhood. Religious leaders are very influent people among the community and it is essential to continue to involve them in the project.

$>$ It might be contemplated to strengthen daily links between the centre and the community, following the example of the Butterflies Programme in India. Rather than creating its own infrastructure, Butterflies taps community resources. Instead of buying premises in which to hold meetings, do theatre work and other activities, it has acquired the use of a room rent free from the local authorities. Instead of providing occupational training, it negotiates with local workshops and businesses to set up apprenticeships for teenagers who decide they want to learn a skill. How could we develop both-sides- relationships between the centre and the community? The centre could provide the surrounding community with certain services and in turn the community would change its behaviour towards street working children..

However, since the project was implemented, it has appeared quite difficult to communicate and collaborate with local community who has been severely affected by years of war, exodus, poverty, social and racial tension. People mistrust or misperceive the work Tdh is doing in Danishabad. Their expectations do not correspond to Tdh's views and perceptions of street working children's needs. Children's social and cognitive development is not considered a priority by majority of the community whose material needs prevail. It seems therefore more relevant to strengthen the links with the mullahs, the most respected and influent persons in the neighbourhood, while maintaining regular but less frequent contacts with community leaders, e.g. organising meetings every three months.

Not all the children attending the centre are self-employed. It is then essential to identify and get in touch with the children's employers to safeguard better working conditions and raise awareness about the children's need to acquire vocational skills rather than be exploited as slaves. Social workers could individually visit the employers while apprenticeship schemes could jointly be elaborated and implemented.

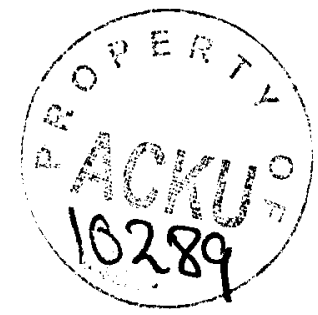




\section{3) Media and networking}

Networking with other agencies involved with street children in the same area ensures the coherence and relevance of Tdh project. It is essential to avoid duplication of the activities and waste of time, energy and money. Sharing information and experiences between organisations enables to capitalize on the others' achievements so as to provide children with better facilities and opportunities in a shorter time and a more adequate and reliable way.

Networking enables to build coalitions on a specific issue. A united voice has generally more impact on decision-makers and opinion-formers than separate isolated voices. A coalition gets a larger audience and more legitimacy for general public.

\section{Suggestions:}

Contacts were made with other agencies implementing programmes for street and/or working children in Peshawar and other places in Pakistan and all around the world. That might be interested to further maintain these contacts, sending regular information about the objectives and achievements of Tdh project. A brief newsletter presenting the steps taken in the social, educational, health..., fields could be written and largely diffused to NGOs, community leaders, political authorities and medias at least twice a year.

Media is a useful tool to be used in a careful way. Diffusing information about one's project in newspapers, TV or radio programmes, is a good way to get known from the general public. Mediatisation leads to people's sensitisation and fund-raising. Nevertheless any organisation involved with children or any disadvantaged population should be careful when using the media, particularly the international media. Not all publicity is good publicity. Journalists sometimes prioritise sensationalism rather than human dignity and diffuse images and comments that severely affect people's self-esteem. It is thus essential to previously contact the journalists to draw-up a common agreement on what should be said and shown and how it should be presented.

\section{Suggestions:}

Contacts should be taken with the local press. Articles could be easily written by some staff members on the specific issue of street working children in Danishabad to increase the general public's level of awareness and promote attitudinal change. 


\section{PROMOTING ADVOCACY IN ASCHIANA IN KABUL}

\section{Background}

Aschiana is an Afghan street children organisation that was founded in 1995 by its current director Engineer Youssef. Its formation was a direct response to the occurrence of thousands of children begging and working in the streets of Kabul as a consequence of years of war, destruction of rural and urban infrastructures, forced displacements of population and impoverishment.

Aschiana is working as Terre des hommes' partner in Kabul. It is currently running 5 centres and a sixth health centre for girls, reaching a total of 2006 children aged between 5 and 16, working in the streets as scavengers, beggars, shoe-polishers, water sellers... Aschiana provides children with services and facilities such as religious education, basic education, recreation, vocational training (painting, flower-making, tailoring, carpentry, wood engraving, calligraphy, (non)electric repairing...), health education, access to basic healthcare, nutrition and awareness about narcotics and landmines.

Aschiana aims at creating opportunities to develop life survival skills among children and saving them from doing useless (education wise), worthless (profit wise) and harmful work. Its objectives are to contribute to improve social, economic, psychosocial and cultural conditions of poor, vulnerable and war-affected children, through service-delivering, while creating knowledge and awareness and promoting action among local community and government authorities, through a rights-based approach.

\section{Aschiana's advocacy strategy}

Much has been done by Aschiana in the field of advocacy since 1995. Despite fighting, unstable political situation and threats by the Taliban regime, Aschiana has been advocating children's rights in an effective and courageous way.

\section{1) Collecting and diffusing information}

Two quantitative assessments on street working children in Kabul were conducted by Aschiana in 1996 and 2002. Respectively about 28.000 and 37.284 children were found begging and working in the streets of Kabul. These surveys were largely diffused to non-governmental agencies and governmental authorities.

Aschiana children are currently selling a newsletter published by AINA, a French organisation, in the streets of Kabul. They get economic benefit from it and increase the knowledge of general public about their situation.

\section{2) Awareness-raising}

Aschiana provides a limited number of children and mothers with regular trainings on $\mathrm{CRC}$, health education and mines hazards. Aschiana teachers regularly participate in trainings on CRC and gender issues organised by other agencies present in Kabul, e.g. 'Save the Children Alliance'. Aschiana psychologist provides staff members with weekly workshops on psychosocial issues and trauma.

\section{3) Promoting children's participation}

During years of war, Aschiana's projects survived with a top-down approach. In the current process of reorganisation, Aschiana is willing to encourage children's greater participation. Children should play an active role in the enjoyment of their rights.

In May 2002, Aschiana children attended a clown spot event in Kabul football stadium, provided by an American company. Unfortunately, only boys enjoyed the rally as girls were not allowed to enter the stadium. 
Nine orphans of war victims from Aschiana participated in an Orphans International Summer Camp organised by Japanese agency 'ASHINAGA' for two weeks in August 2002. The camp took place in Kobe, a Japanese city partly demolished by an earthquake in 1992. It involved 160 child participants from cities or countries severely affected by war or natural disasters, as Afghanistan, New York (USA), Turkey, Uganda, Colombia, Taiwan and Kobe (Japan).

10 children actively participated in Aschiana four-day planning workshop in October 2002. The workshop was organised jointly with 'Terre des hommes' to decide on the orientations of Aschiana for the next three years.

\section{4) Self-advocacy}

On November 20,2000, under the Taliban regime, Aschiana celebrated the 'Day of the child' on the occasion of the $11^{\text {th }}$ anniversary of the Convention on the Rights of the Child (CRC). Drama and art exhibitions were performed by child boys (girls had been expelled from Aschiana centres in 1998) while banners painted by children were displaying verses from Holy Quran regarding childcare and female rights. The ceremony was tolerated by the Talibans. Aschiana opened negotiations to promote child girls' rights and, in May 2001, a health education centre was established for 300 girls, after Tdh and Aschiana signed a joint agreement with the Taliban government.

Aschiana children have presented the art works produced in vocational training activities in temporary exhibitions. The last one was organised jointly by French organisation AINA and Democratic Party of Japan for one week in August 2002. The art exhibition was successfully visited by numerous expatriates working in non-governmental and international agencies in Afghanistan. It was followed by a concert conducted by Japanese organisers in Aschiana. About 1.500 children attended the event. Aschiana is now establishing a permanent art gallery in its main centre to enable children to present their art works to their families and foreign visitors.

Child-to-child approaches have been implemented by Aschiana, including former Aschiana children who got their certificate from vocational training activities and opened their own businesses. Collaboration between Aschiana and existing workshops might thus be strengthened to ensure that Aschiana children find themselves employed after they achieved professional training.

\section{5) Increasing community's involvement}

Local community has been indirectly involved in Aschiana. Links with children's families and local community have been established by Aschiana social workers, who visit children's homes and workplaces in a more or less unsystematically way, discuss their current problems and report difficulties to Aschiana.

Parents visit Aschiana centres on a voluntary basis, when they have some problems or need any information regarding their children. Good relationships have been established and maintained with surrounding mosques, schools and elders. They generally appreciate the work Aschiana is doing with street working children.

Corporate sector is informally involved in Aschiana through monthly tours to service shops and mechanical workshops within Kabul. Aschiana social workers arranges visits for children to industrial and vocational centres, to wake up their interest for different kinds of professions and help them choose the trade they want to learn in Aschiana, according to their talent and willing.

Aschiana is thinking to improve the representation and participation of the community and children in decision-making and current running of the projects. One option contemplated would be to establish a steering committee representing all stakeholders involved in the projects ${ }^{4}$.

\footnotetext{
${ }^{\dagger}$ ASCHIANA, Annual repont, 200I.
} 


\section{6) Lobbying political authorities}

Aschiana has experienced major changes as far as the government as a stakeholder is concerned. Relationships with the new government are not bad but it is unlikely that the issue of street working children will be recognised as a priority compared to infrastructure reconstruction or food support before winter time.

Lakhtar Brahimi. United nations' special Envoy for Afghanistan, EU Commissioner for humanitarian affairs, foreign Parliamentarians and Ministers, like German Minister for economic cooperation, visited Aschiana in the last few months. They all congratulated Aschiana for its current action and achievements. It cannot be expected much from such official visits but it is to be hoped that national and international stakeholders are getting sensitised to street working children issue. Diffusing information through newsletters and annual reports might encourage them to design and implement adequate health and education policies.

\section{7) Networking}

Relations with other agencies involved with children or humanitarian assistance in Afghanistan have been severely affected by the installation of the Taliban regime and their attitude less than unfavourable to foreign organisations. Close collaboration had been established with UNHCR, UNICEF, Save the Children Alliance (Sweden/UK), ICRC, CARE International, Pharmaciens sans frontières, Children in Crisis... Most of these regular contacts were broken when foreign agencies had to leave the country under the Taliban regime.

Terre des hommes has been the closest organisation to Aschiana from its creation. Tdh is Aschiana's main funder but also a partner which promotes efficiency, effectiveness and relevance to Aschiana's programmes. Through its partnership with Terre des homes, Aschiana has established contacts with Aparajeyo Bangladesh and Tdh Street working children's project in Peshawar.

\section{8) Media}

Media should be carefully used. Mediatization enables Aschiana to get known in Afghanistan and abroad but it is essential to avoid any kind of sensationalism. Press articles and TV/programmes should be carefully monitored to ensure that children's dignity is respected and the information provided is reliable.

Many foreign journalists have visited Aschiana for the last months, publishing articles or broadcasting TV programmes throughout the world through famous channels such as $\mathrm{BBC}$ or $\mathrm{CNN}$. Media is a good way to gain support and funds but, due to competitive constraints, it tends towards sensationalism and must be used carefully. Aschiana is wondering if it has really benefited from media.

\section{9) Fundraising}

Local fundraising did not take place until now. It could be further developed through local exhibitions of items produced by children in vocational training activities. The sale of children's production mostly enables Aschiana to purchase raw materials. The profit is given back to children.

Two sets of postcards were produced by Aschiana, reproducing children's paintings, in 2000. New models have been published by 'Terre des hommes' and should be sold this year, in Kabul and Switzerland. Other items produced by children were sent to Tdh headquarter in Lausanne and sold there. Tdh might contemplate to develop a mail-order business, offering postcards and other items such as calendars. 


\section{BIBLIOGRAPHY}

- Casa Alianza, Trabajo infantil :Vision de Conjunto, http://casa-alianza.org/

- ChildHope (UK) and BICE (Bureau International Catholique de l'Enfance), Street children: Resource Sheets for Project Management.

- Consortium for Street Children - UK, Anti-Slavery International, Child Labour in the Informal Urban Sector: From individual working children to a national plan, Funded by the Department for International Development, 21 September 1999.

- Consortium for Street Children - UK, Background paper on Street Children and Violence, based on a presentation by Marie Wernham, Advocacy Officer, at UN Commission on Human Rights, $57^{\text {th }}$ Session, 9 April 2001.

- Consortium for Street Children - UK, Panel Discussion: Promoting and Protecting the Rights of Street Children, 13 June 2001, UN General Assembly Special Session on Children, Third PrepCom, NY.

- Consortium for Street Children - UK, Violence Against Children Within the Family, written submission to UN Committee on the Rights of the Child, Day of General Discussion, 28 September 2001.

- Consortium for Street Children-UK, Advocacy Workshop Report, 5 November 2001.

- Consortium for Street Children - UK, in partnership with ChildHope and Protecting Environment and Children Everywhere (PEACE), Civil Society Forum for South Asia on Promoting and Protecting the Rights of Street Children, Colombo, Sri Lanka, 12-14 December 2001.

- DUBBLE Cindy, Needs assessment of working children in Mazar-I-Sharif, Save the Children Unicef, 1997.

- ENNEWI Judith, Street and working children - A guide to planning, Development Manual No. 4, Save the Children, 1994.

- HAFEEZ Sabeeha, The girl child in Pakistan - Priority concerns, Unicef, 1990. 
- HRMDC (Human Resource and Development Centre), Their name is tomorrow... - The working children of Peshawar, Peshawar, 1996.

- HUDSON Alan. Linking the levels? The organization of UK development NGOs' advocacy - $A$ summary report for NGOs and research participants, 17 July 2000.

- International Save the Children Alliance, Child Rights Programming - How to apply rights-based approaches in programming.

- JILLANI Anees and Zarina, Child rights in Pakistan, SPARC, Islamabad, January 2000.

- LANSDOWN Gerry, Promoting children's participation in democratic decision-making, Unicef, 2001 .

- PRADHAN Gauri, Advocacy - How to engage with policy makers and practitioners at the national level so as to influence policy and practice?, CWIN, Regional Alliance Workshop on childcentred policies and programmes for working children in South and Central Asia, Kathmandu, Nepal, 9-12 May 2002.

- Save the Children - Sweden, Afghanistan's children - Speak to the UN Special Session, $19^{\text {th }}-21^{\mathrm{st}}$ September 2001, Peshawar, 2001.

- Save the Children - Sweden, Mobilisation for self-help and child rights - Lessons learned in Afghan refugee camps, 1983-2002, Peshawar, 2002.

- $\quad$ SPARC. The state of Pakistan's children, Islamabad, Pakistan, 2002.

- $\quad$ STOECKLIN Daniel, Children in Street Situations - Terre des Hommes Strategy, Fondation Terre des Hommes, Lausanne, 15 février 2002.

- SWIFT Anthony, Working children get organized - An introduction to working children's organizations, Save the Children Alliance, 1999.

- TEARFUND, Advocacy toolkit - Understanding advocacy, 2002. 


\section{CONTENTS OF APPENDIX}

Aparajeyo - Bangladesh

Concern for Children and Environment (CONCERN) - Nepal -

Fundatia 'Familia si Ocrotirea Copilului' (FOC) - Romania -

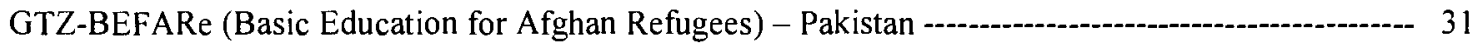

Human Resources Development and Management Centre (HRMDC) - Pakistan ------------------------- 32

ILO - IPEC (International Programme on the Elimination of Child Labour) - Pakistan ---------------- 32

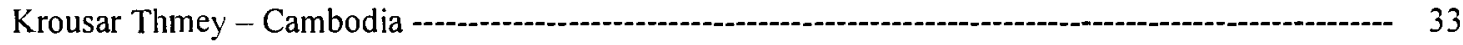

Society for the Protection of the Rights of the Child (SPARC) - Pakistan ------------------------------ 33

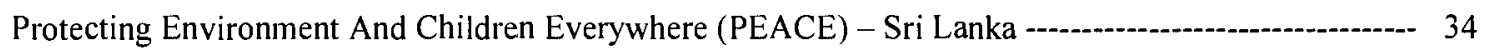

Swabi Women Welfare Society (SWWS) - Pakistan -

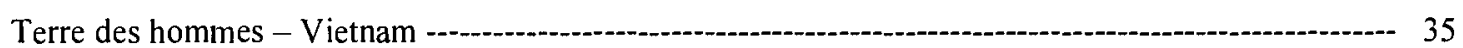

Consortium for Street Children (CSC) - UK -

Save the Children - Sweden (SC-S) -

ANNEX 2: USEFUL CONTACTS --.-- 38 


\section{ANNEX 1: EXAMPLES OF GOOD ADVOCACY PRACTICES}

Here are summarised several innovative approaches and initiatives to address the needs and rights of street children. The best practices presented as followed have been experimented in Pakistan and other south Asian countries such as Bangladesh, Nepal, Sri Lanka and Cambodia, and in Eastern Europe (Romania). This presentation is not exhaustive. The achievements of each organisation are presented very briefly and many others agencies would be worth mentioning. To contact the following organisations, please refer to Annex 2.

\section{APARAJEYO - BANGLADESH}

Aparajeyo - Bangladesh (AB) was established in 1976 and is working as Terre des hommes' partner in Bangladesh. AB provides children living in slum areas, on the City's streets or amongst its public buildings, with personal services designed to improve their quality of life. Around 25.000 disadvantaged children attend 4 drop-in centres, 2 residential clubs and 2 hostels for girls and boys on a regular basis.

$\mathrm{AB}$ works through a bottom-up approach based on the principles of commitment and transparency. AB's objective is to empower children so that they can contribute actively to their own development.

\section{AB's advocacy strategy}

$>$ Building up a solid reputation: AB has created its reputation in Bangladesh. Its programmes for street children constitute a replicable model of good practices and give it credibility and legitimacy to advocate.

$>$ Awareness-raising: 'Action Committees' and 'Advisory Committees' maintain regular contacts with local authorities, child employers and the community.

Networking and partnership: joint partnership programme with the government to make them concerned about child rights issues and help them develop a model of best practice, networking with other organisations and stakeholders, consultations with donors and UN bodies.

Lobbying: working collectively to create pressure on decision-makers to undertake policies.

\section{CONCERN FOR CHILDREN AND ENVIRONMENT (CONCERN)}

CONCERN is an organisation working for the improvement of child labourers' lives and working conditions in Nepal. Its action to reduce child labour is guided by a set of best practices, including action research work, service-delivering, community and parents' involvement, child club formations, micro-credit and saving activities, registration of local industries and birth registration.

\section{Advocacy tools}

$>$ Self-advocacy: essay competition for literate child workers, child photographers' photo exhibition or child painting competition on child labour, rallies on children's day or CRC day, press conference.

$>$ Awareness-raising: meeting with local community, trainings on CRC for working children.

$>$ Networking and lobbying: regular meetings with local authority.

Involvement of corporate sector: data-collecting and regular monitoring of local industries. 


\section{FUNDATIA « FAMILIA SI OCROTIREA COPILULUI »}

Tdh - Romania's partner Fundatia "Familia si Ocrotirea Copilului" (FOC) has been implementing a social prevention program since 1998 to address the issues of drop-out at school, child labour and child abuse in the chaotic aftermath of the Communist regime.

FOC's main objectives are to raise awareness in children on education as a means to acquire professional skills, to empower parents so that they can assume their educational role, and to give support to disadvantaged families within local community.

FOC promotes and facilitates street children's social reinsertion through servicedelivering and psychological and economical accompaniment of their families.

\section{Advocacy strategy}

> Collecting and disseminating information: database, statistics, social studies, research, experience capitalisation.

$>$ Publication of a "Guide for social workers" in 2001, which contemplates the issue of street children at several levels (sociological, psychological, educational and health).

$>$ Self-advocacy: rallies and events organised by/with children in difficult circumstances (expositions, concerts, handicrafts).

$>$ Awareness-raising: social assistance to the families, regular parents meetings, trainings of social workers from other organisations and students in social sciences.

$>$ Networking: with Social Department for Childhood Protection, policy-makers and NGOs.

$>$ Media: media coverage of public events.

\section{GTZ - BEFARe (Basic Education For Afghan Refugees)}

GTZ - BEFARe has been present since 1987 in 40 major Afghan refugee camps in Pakistan's NWFP (North West Frontier Province), providing Afghan families with education facilities.

\section{Advocacy strategy}

$>$ Self-advocacy: 'Child-to-Child Associations' and 'Old Students Associations' play a pivotal role in attracting street working children to the schools as in disease prevention, hygiene and skill development.

$>$ Community participation: 'School Management Committees' provide effective community assistance to the schools, raise funds for the maintenance and improvement of the schools, ensure children's school attendance, campaign for children not attending primary school.

Awareness-raising: Parents' day, sport competitions, debate competitions on issues such as children's rights, drug abuse or child labour.

$>$ Networking: Camp level organisations maintain regular contacts with other organisations throughout the Province. 


\section{HUMAN RESOURCES MANAGEMENT AND DEVELOPMENT CENTRE (HRMDC)}

HRMDC was established in Peshawar (Pakistan) in March 1994 to promote 'People-centred development' and develop local human resources through service-delivering, training, research, community development, dissemination of information, policy-dialogue and networking.

HRMDC is currently running six Mashaal - centres for 450 working children in Peshawar District, providing non-formal education, life skills and recreation opportunities.

\section{Advocacy strategy}

$>$ Self-advocacy: Certificate Distribution Ceremonies are organised twice a year, where children are given the opportunity to present jokes, songs and speeches.

$>$ Awareness-raising: Children attend weekly workshops on education, child rights, environment and health

> Community involvement: Parents-Teachers-Employers Associations meet regularly, discuss issues such as child labours and manage the running of the centres.

Collecting and disseminating information: in-depth researches on working children in Peshawar District, bi-annual Mashaloona newsletter.

Networking: with UNICEF, local authorities, local/international media, NGOs and CBOs.

D Fund-raising: sponsorship of working children on a monthly or yearly basis, sale of research books, greeting cards and post cards, individual or group donations.

\section{ILO (International Labour Organisation) - IPEC (International Programme on the Elimination of Child Labour)}

ILO - IPEC is currently supporting the project 'Combating Child Labour through education and training'. The project involves governmental and non-governmental actors. Its objectives are to integrate child labour issues into social, economic and developmental policies, to promote universal basic education and to develop a skilled labour workforce in an institutionalised manner.

Nine rehabilitation centres have been established in Peshawar District, providing 1.060 working children with basic education and pre-vocational training.

\section{Advocacy strategy}

Collecting information: database and baseline study on the target group of the project, policy studies on educational and legal framework and occupational hazards.

$>$ Awareness-raising: realisation of a child labour information kit, awareness workshops for employers, parents, government officials, teachers, students, lawyers and general community.

> Partnership: with NGOs, Provincial authorities and Departments of University of Peshawar. 


\section{KROUSAR THMEY}

Krousar Thmey is an apolitical non-religious Cambodian organisation that was established in 1991. It provides deprived children with educational, social and cultural support in harmony with their environment and respectful of their traditions.

Krousar Thmey is currently running 35 programmes in 6 provinces in Cambodia, providing children with protection and welfare, education and schooling support and aid to cultural and artistic development.

\section{Advocacy}

$>$ Self-advocacy: celebration of the anniversary of Krousar Thmey by child beneficiaries and staff every two years, through games, theatre performances, debate competitions on cultural issues, cultural visits..

$>$ Awareness-raising: workshops on children's rights provided to children, trainings on health care, child exploitation and domestic violence provided to street children's parents.

Capacity-building: supporting leader development in the field of social services to better address public education and child protection.

Detworking: monthly meetings of NGOs street children task force, regular contacts with UNICEF and Ministry of Social Affairs

$>$ Mediatisation: visit of Krousar Thmey programmes by famous French actors Carole Bouquet and Gerard Depardieu on May $31^{\text {st }}, 2002$.

Fundraising: sponsorship abroad, European volunteers in charge of financial management and public relations.

\section{SOCIETY FOR THE PROTECTION OF THE RIGHTS OF THE CHILD (SPARC)}

SPARC is a Pakistani research based non-profit and non-governmental organisation. Since 1992, it has been working on Human rights issue, with special emphasis on children's rights. SPARC operates through three regional offices in Islamabad, Peshawar and Lahore, and plans to establish a countrywide network of offices and crisis centres in a near future.

SPARC's organisational strength lies mainly in its capacity for analytical research and creative search for alternative options to improve children's situation in Pakistan. Its objective is to study, analyse and disseminate information to raise the level of awareness of policy-makers and general public, provoke legislative change and provide a platform for children's voice to be heard.

\section{Advocacy}

Collecting information: constant assessment of the state of children in Pakistan through regular studies, research and analysis, regular release of user-friendly publications on childcare and child-rights issues.

$>$ Networking: collaboration with other agencies in collecting and analysing child-related data and in the dissemination of their findings.

Lobbying: mobilisation of individuals, groups and communities to express their deep concern about lack of political will in government policies and/or their implementation (e.g. petition campaigns), action against evident violation or denial of children's rights.

> Moniloring: vigilant attention to new government legislation, making it known to general public and those involved with children, thereby promoting wider public dialogue and scrutiny of such Inim 


\section{PROTECTING ENVIRONMENT AND CHILDREN EVERYWHERE (PEACE)}

PEACE is a campaign launched in 1989 in Sri Lanka against the commercial sexual exploitation and abuse of children by both local and foreign paedophiles. It is affiliated to ECPA International (End Child Prostitution, Child Pornography and Trafficking of Children for Sexual Purposes) based in Bangkok, Thailand.

PEACE has implemented 40 programmes for children living in slums, on the streets or on beaches. Its objective is to deliver services to populations at risk, create awareness on the issue of child sexual exploitation and influence policy-makers.

\section{Advocacy strategy}

$>$ Collecting and disseminating information: conducting regular research and studies about child sexual or labour exploitation, publishing a quarterly trilingual newsletter diffused at local, national and international levels.

$>$ Self-advocacy: annual 'Celebration of the Child' on the anniversary of the CRC on November $20^{\text {th }}$ (exhibition of children's work including arts and handicrafts, socio-drama by the children, workshops, public meetings).

D Leadership programmes: workshops for children on the theme 'Grow where you are planted', trainings on the $\mathrm{CRC}$.

> Awareness-raising: meetings, seminars, workshops, conferences with government, NGOs, students, professionals and religious leaders; public meetings and press conferences.

Networking: with the Government, local and foreign organisations.

> Media: using available mass media facilities and producing video films on child sexual exploitation and hazardous work.

> Lobbying the Government: directly and through national and international bodies, to strengthen and/or amend existing legislation in the areas of child sexual exploitation, child labour and juvenile justice.

Legal monitoring programmes: making available the services of lawyers to the child victims and promoting the enforcement of the law. 


\section{SWABI WOMEN WELFARE SOCIETY (SWWS)}

Swabi Women Welfare Society (SWWS) was established in 1991 for the promotion of women's development in Mardan division (NWFP, Pakistan), focusing on socio-economic, health, population welfare, education and environment issues on a self-help basis.

SWWS has implemented reproductive health and economic programmes which main objectives are poverty alleviation and community's empowerment. In August 2000, SWWS had provided reproductive health services to 35.000 women in 66 villages. SWWS is currently operating 10 schools for 700 male and female Urban Working and Indigent Children in Mardan City.

\section{Advocacy strategy}

$>$ Collecting and disseminating information: research, case studies, identification of the problem, target group and stakeholders, fact sheets.

$>$ Community participation: Parents-Teachers-Associations, School Management Committees and $\mathrm{MCH}$ Management Committees participate in the management and maintenance of the schools and health centres, inform and mobilize the community and minimize health hazards.

$>$ Awareness-raising: trainings and capacity-building.

$>$ Networking: coalition and linkages with policy-makers and other organisations.

$>$ Media: printing of articles, regular column in newspapers.

Fund raising: sponsorship on an individual basis.

\section{TERRE DES HOMMES - VIETNAM}

Tdh Vietnam is working to improve life conditions of children in difficult circumstances in Southern Vietnam, including children in conflict with the law, child victims of prostitution, child drug abusers, HIV positive children, orphans, disabled children and street children.

Tdh Vietnam is working through partnerships with local organisations. It has implemented eight projects with three local partners to address the issue of street children, delivering services and promoting socioprofessional integration.

\section{Advocacy strategy}

$>$ Collecting and disseminating information: Tdh Vietnam sponsored a major study on the situation of street children in Ho Chi Minh City.

i Community participation: The neighbourhood, local ward, police station and mass organisations are jointly monitoring community-based houses.

$>$ Awareness-raising: Tdh Vietnam sponsored and participated in a national-international conference about the situation of street educators and street children in Vietnam. This event was covered nation-wide by radio and TV channels.

$>$ Networking and policy dialogue: Regular meetings with the Department of Social Affairs in Ho Chi Minh City, the Aids Committee of Can Tho and the Committee for Population, Family and Children, monthly meetings of Ho Chi Minh City's INGO Children's group with political authorities, local organisations and INGOs. 


\section{CONSORTIUM FOR STREET CHILDREN (CSC) - UK}

The Consortium for Street Children (CSC) - UK is a network of 40 NGOs working with street-living children, street-working children and children at risk of taking to street life in Africa, Asia, Latin America, and Eastern and Central Europe.

CSC was launched in 1993 by agencies and individuals working for the rights of street children. Their common objective was to pool their expertise and collaborate with each other in order to achieve a greater impact.

CSC aims at improving the quality and stability of projects that serve street children and preventing further generation from being forced to live and work on the streets.

\section{Advocacy steps}

$>$ Networking: CSC works with a wide network of UK-based development agencies that provide funding, operational partnership, training, advocacy and campaigning support to projects for street children.

Sharing information: establishment of Regional Civil Society Forums aimed at strengthening participative partnerships between civil society organisations and governments, to help them identify and share good practices at work.

Capacity-building: $\mathrm{CSC}$ is in the process of establishing task-forces on health and nonformal education, bringing together experts from NGOs, UN agencies and academic institutions, in order to identify realistic, appropriate actions that will improve living conditions of street children.

$>$ Lobbying decision-makers: CSC provides a collective voice for lobbying on issues affecting street children and channelling the concerns of its partners to wider national and international audiences. CSC lobbies the UK government and works with the Human Rights Committee of England and Wales to mobilise immediate political response to human rights against street children.

Policy-development: $\mathrm{CSC}$ advocates long-term and sustainable solutions to street children issues through regular input into a range of UN mechanisms (Commission on Human Rights, Committee on the Rights of the Child, thematic Special Rapporteurs, follow-up to the Special Session on Children) and through the Global Movement for Children campaign. 


\section{SAVE THE CHILDREN - SWEDEN}

Rädda Barnen (Save the Children - Sweden) is a non-governmental organisation, independent of political party or religion, which has 85.000 members. Save the Children - Sweden (SC-S) has been working in Afghan refugee camps in North West Frontier Province in Pakistan since 1983.

SC-S mainly acts through developing knowledge about children's conditions and needs, sponsoring practical development, supporting programmes and disseminating the experience gained, and influencing public opinion and decision-makers.

SC-S's work is characterized by respect for the child and his/her right to participate in all matters affecting his/her life. SCS does not directly implement programmes. It works through partnerships with local organisations

\section{Advocacy strategy}

$>$ Networking: SC-S cooperates with other NGOs, UN agencies, universities and research institutes all over the world, convinced that advocacy has more impact when organisations work together. In Pakistan, SC-S has been working in close partnership with UNHCR and Commissionate for Afghan refugees.

$>$ Awareness-raising: trainings on CRC and gender issues provided to the community, Action for the Rights of the Children (ARC) introduced in 1998 to give refugee youngsters comprehensive care and protection.

Dapacity-building: training of SC-S partners' staff members on issues such as CRC, gender, community mobilisation and child-to-child approaches, training of community volunteers, training of social animators to interlink the community with assistance organisations.

$>$ Community mobilisation: establishment of Social Welfare Committees and Social Welfare Cells in all camps to represent local community and promote collective action, establishment of self-help schools home-based and ran by volunteer teachers, establishment of Youth Welfare Organisations to organise sport and cultural events and promote community development.

Self-advocacy: establishment of child-to-child groups to monitor child rights in their schools and communities and promote the rights to education by visiting the families where children do not attend school, active involvement of children in spreading messages about children's rights, health, environment...

$>$ Children's participation: children's participation in rallies such as environmental days, initiatives by children to improve their environment (e.g. planting trees or gardening). 


\begin{tabular}{|c|c|c|c|c|c|}
\hline ORGANISATION & CONTACT & ADDRESS & PHONE NUMBER & FAX NUMBER & EMAIL \\
\hline $\begin{array}{l}\text { ACBAR (Agency Coordinating Body for } \\
\text { Afghan Relief) - ARIC (ACBAR Resource } \\
\text { and Information Centre) }\end{array}$ & & $\begin{array}{l}\text { 2, Rehman Baba Road, UPO 1084, Peshawar, } \\
\text { Pakistan }\end{array}$ & $\begin{array}{l}009291 \\
850839 / 5704392 / 57025 \\
31 \\
\end{array}$ & & aric@brain.net.pk \\
\hline $\begin{array}{l}\text { Afghan Women's Educational Centre } \\
\text { (AWEC) }\end{array}$ & Palwasha Hassan & $\begin{array}{l}\text { Wahidabad, opp. Islamia College, Jamrud Road, } \\
\text { Peshawar, Pakistan }\end{array}$ & 009291844028 & & irfan@pes.comsats.net.pk \\
\hline Afghanistan Demain & Eshan Mehrangais & & $0093(0) 70278409$ & & afghanistandemain@hotmail.com \\
\hline Aparajeyo Bangladesh (AB) & $\begin{array}{l}\text { Isthiaque Ahmed } \\
\text { (Executive Director) }\end{array}$ & $\begin{array}{l}\text { 2/5 Humayan Road, Block B, Mohammadpur, } \\
\text { Dhaka } 1207 \text {, Bangladesh }\end{array}$ & 88028115798 & 88028110380 & apribd@bol-online.com \\
\hline $\begin{array}{l}\text { ASCHIANA (Afghan street working children } \\
\text { and new approach) }\end{array}$ & $\begin{array}{l}\text { Engineer Mohammad } \\
\text { Yousef }\end{array}$ & $\begin{array}{l}\text { House \#231, Opposite Industrial Development } \\
\text { Bank, Shahr-e-Now, Kabul, Afghanistan, P.O. } \\
\text { Box No. } 1827\end{array}$ & & & medairkbl@atge.automail.com \\
\hline $\begin{array}{l}\text { Basic Education for Afghan Refugees } \\
\text { (BEFARe) - GTZ }\end{array}$ & Jonaid Shah & $\begin{array}{l}\text { 8, Tatara Road, Rahat Abad, PO Box } 1481 \text {, } \\
\text { Peshawar, Pakistan }\end{array}$ & $\begin{array}{l}009291840631 / \\
42955\end{array}$ & 009291841047 & befare@psh.brain.net.pk \\
\hline $\begin{array}{l}\text { British Overseas NGOs for Development } \\
\text { (BOND) }\end{array}$ & $\begin{array}{l}\text { Jenny Ross (Advocacy } \\
\text { Officer) }\end{array}$ & $\begin{array}{l}\text { Regent's Wharf, } 8 \text { All Saint's Street, London NI } \\
\text { 9RL, UK }\end{array}$ & 00442078378344 & 00442078374220 & $\begin{array}{l}\text { jross@bond.org.uk } \\
\text { www.bond.org.uk/advocacy }\end{array}$ \\
\hline Child Workers in Asia (CWA) & Edelweiss Silan & Bangkok, Thailand & $\begin{array}{l}066-2-930-0855 \text { or } 930- \\
5316\end{array}$ & $066-2-930-0856$ & coord@cwa.tnet.co.th \\
\hline ChildHope UK & $\begin{array}{l}\text { Geoff Cordell } \\
\text { (Programme Otficer) }\end{array}$ & $\begin{array}{l}\text { Lector Court, } 151 \text { Farrington Road, London } \\
\text { EC1R3AF, UK }\end{array}$ & 442078330868 & 442078332500 & $\begin{array}{l}\text { Chuk@gn.apc.org } \\
\text { geoff@childhopeuk.org }\end{array}$ \\
\hline Childline India Foundation & $\begin{array}{l}\text { Jeroo Billimoria } \\
\text { (Honorary Secretary) }\end{array}$ & $\begin{array}{l}\text { Nana Chowk Municipal Road, 2nd floor, Frere } \\
\text { Bridge, Low Level, Nana Chowk, Mumbai } 400 \\
\text { 007, India }\end{array}$ & $\begin{array}{l}91223881098 / 387 \\
1098\end{array}$ & 91223811098 & $\begin{array}{l}\text { jeroob@vsnl.net } \\
\text { dial1098@childlineindia.org.in }\end{array}$ \\
\hline Children in Crisis & Louise Ambler & $\begin{array}{l}\text { \#281 Street 15, Wazir Akbar Khan, Kabul, } \\
\text { Afghanistan }\end{array}$ & $0093(0) 70281401$ & & caicic@aol.com \\
\hline $\begin{array}{l}\text { Concern for Children and Environment } \\
\text { (CONCERN) }\end{array}$ & $\begin{array}{l}\text { Bijaya Sainju } \\
\text { (Chairperson) }\end{array}$ & $\begin{array}{l}\text { PO Box 4543, Swoyambhu Area, Kathmandu, } \\
\text { Nepal }\end{array}$ & $\begin{array}{l}9771280754 / 282 \\
809\end{array}$ & 9771277033 & concern@mos.com.np \\
\hline Consortium for Street Children (CSC) UK & Marie Wernham & $\begin{array}{l}\text { Unit } 306 \text { Bon Marche Centre, 241-251 Ferndale } \\
\text { Road, London SW9 8BJ, UK }\end{array}$ & 00442072740087 & 0044202740372 & $\begin{array}{l}\text { marie@streetchildren.org.uk } \\
\text { www.cscuk.org.uk }\end{array}$ \\
\hline $\begin{array}{l}\text { ENDA Jeunesse Action - African Movement } \\
\text { of Child and Youth Workers }\end{array}$ & Aime Bada & 4-5, rue Kleber, BP 3370, Dakar, Senegal & $\begin{array}{l}002218224229 / \\
216027\end{array}$ & 002218222695 & $\begin{array}{l}\text { eit@enda.sn enda@enda.sn } \\
\text { www.enda.sn }\end{array}$ \\
\hline $\begin{array}{l}\text { Enfants du Monde - Droits de l'Homme } \\
\text { (EMDH) }\end{array}$ & $\begin{array}{l}\text { Jacques Hiriart (Head of } \\
\text { Mission) }\end{array}$ & $\begin{array}{l}\text { House 60, Street 1, Karter Mamoorin, District } 5 \text {, } \\
\text { Kabul, Afghanistan }\end{array}$ & $0093(0) 70282337$ & & emdhafgha@oceanpost.net \\
\hline $\begin{array}{l}\text { Fundatia "Familia si Ocrotirea Copilului" } \\
\text { (FOC) }\end{array}$ & $\begin{array}{l}\text { Jean-Luc Imhof (Delegue } \\
\text { regional Tdh - Europe de } \\
\text { l'Est) }\end{array}$ & $\begin{array}{l}\text { Rue Pericle Gheorghiu nr 15, sect 5, Bucarest, } \\
\text { Romania }\end{array}$ & $40(01) 3366354$ & $40(01) 3374863$ & foc@dial.kappa.ro \\
\hline GODH Lahore - Gypsie Children & Nazir Ahmed Ghazi & $\begin{array}{l}\text { House \#4, Street \#27, Canal Park, Main Bazor, } \\
\text { Gulberg 11, Lahore, Pakistan }\end{array}$ & 0092425879158 & & godh1@hotmail.com \\
\hline
\end{tabular}




\begin{tabular}{|c|c|c|c|c|c|}
\hline $\begin{array}{l}\text { Human Resource Management and } \\
\text { Development Centre }\end{array}$ & Bushra Gohar & $\begin{array}{l}\begin{array}{l}\text { F18 KKK Road, University Town, Peshawar, } \\
\text { Pakistan }\end{array} \\
\end{array}$ & 009291842850 & 009291850920 & hrmdc@brain.net.pk \\
\hline ILO/IPEC & $\begin{array}{l}\text { Shyama Salgado } \\
\text { (National Project } \\
\text { Coordinator) }\end{array}$ & $\begin{array}{l}131 / 4 \text { Thimbirigasaya Road, Colombo } 5 \text {, Sri } \\
\text { Lanka }\end{array}$ & 00941592304 & 00941502692 & slsipec@sitnet.lk \\
\hline International Labour Organization (ILO) & Khalid Hassan & $\begin{array}{l}\text { 47A Defence Officer Colony, Garden Avenue, } \\
\text { Peshawar cantonment, Pakistan }\end{array}$ & 009291279045 & & ipec@pes.comsat.net.pk \\
\hline Krousar Thmey & Sok Phanna & $\begin{array}{l}\text { 4, rue 257, Avenue Kampuchea Krom, Phnom } \\
\text { Penh, Cambodia }\end{array}$ & $\begin{array}{l}0085523366184 / \\
880503\end{array}$ & 0085523882113 & krousar_thmey@bigpond.com.kh \\
\hline Norwegian Refugee Council (NRC) & Tove Fischer & $\begin{array}{l}\text { 64-E Jamal Afghani Lane, University Town, } \\
\text { Peshawar, Pakistan }\end{array}$ & $\begin{array}{l}009291853861 / \\
854872 / 854873\end{array}$ & & nrceduc@brain.net.pk \\
\hline Ockenden International & Roza Gul & $\begin{array}{l}43 \text { D-2, Old Jamrud Road, UT, Peshawar, } \\
\text { Pakistan }\end{array}$ & 009291850410 & & ocken@psh.brain.net.pk \\
\hline $\begin{array}{l}\text { Organisation for Development of Rural } \\
\text { Communities (WESS) }\end{array}$ & $\begin{array}{l}\text { Sardar Iftiknar Khan } \\
\text { (Project Manager) }\end{array}$ & $\begin{array}{l}\text { Drop-in centres for Afghan working children, } \\
\text { Quetta, Pakistan }\end{array}$ & 009281834065 & & wess@qta.paknet.com.pk \\
\hline $\begin{array}{l}\text { Protecting Environment and Children } \\
\text { Everywhere (PEACE) }\end{array}$ & $\begin{array}{l}\text { Maureen Seneviratne } \\
\text { (Chairperson) }\end{array}$ & 166 Thibirigasaya Road, Colombo 5, Sri Lanka & 00941596855 & 00941596855 & peaces!@sri.lanka.net \\
\hline Save the Children Sweden (SCS) & $\begin{array}{l}\text { Anne Siri Rustad } \\
\text { (Programme Manager) }\end{array}$ & H. No 2127, Street-A, Kart-e-Seh, D.6, Kabul & $0093(0) 70278626$ & & scskabul@eikmail.com \\
\hline Save the Children Sweden (SCS) & $\begin{array}{l}\text { Mehmood Asghar } \\
\text { (Project Coordinator) - } \\
\text { Lisa Ludgren (Delegate) }\end{array}$ & $\begin{array}{l}\text { 60-C(5) University Road, University Town, } \\
\text { Peshawar, Pakistan }\end{array}$ & $\begin{array}{l}0092915104784 / \\
840987\end{array}$ & 009291840349 & radda@obrain.net.pk \\
\hline Save the Children UK (SCUK) & $\begin{array}{l}\text { Qais Anwar (Street } \\
\text { children projects) }\end{array}$ & Railway Road, Peshawar, Pakistan & $\begin{array}{l}009291841510 / \\
841839 / 570511 / \\
5704236\end{array}$ & & $\begin{array}{l}\text { scuk-afg@pes.comsats.net.pk } \\
\text { scukpesh@psh.paknet.com.pk }\end{array}$ \\
\hline Save the Children USA & Irene McWeeney & & & & imcweeney@savechildren.org.pk \\
\hline $\begin{array}{l}\text { Society for the Protection of the Rights of the } \\
\text { Child (SPARC) }\end{array}$ & Ances Jillani & $\begin{array}{l}\text { No. 14, Fourth Floor, 109-West, Sardar Begum } \\
\text { Plaza, Blue Area, PO Box 301, Islamabad, } \\
\text { Pakistan }\end{array}$ & 0092512279504 & 0092512279256 & sparc@isb.sdnpk.org \\
\hline $\begin{array}{l}\text { Society for the Protection of the Rights of the } \\
\text { Child (SPARC) }\end{array}$ & $\begin{array}{l}\text { Arshad Mahmood } \\
\text { (National Project } \\
\text { Coordinator) }\end{array}$ & $\begin{array}{l}\text { No. 5, Fifth Floor, Bilour Plaza, Peshawar Cantt., } \\
\text { Pakistan }\end{array}$ & 009291273265 & 009291270210 & sparc@pes.comsats.net.pk \\
\hline Struggle for Change (SACH) & $\begin{array}{l}\text { Khalida Salimi } \\
\text { (Executive Director) }\end{array}$ & House 142 St 99, I-8-4, Islamabad, Pakistan & 0092514446178 & 0092514447400 & khalida@apollo.net.pk \\
\hline Swabi Women Welfare Society (SWWS) & Javed Akhtar & $\begin{array}{l}\text { SWWS House, Sirajpur, Karnal Sher Khan Town } \\
\text { (Nawankilli) Swabi, NFWP - GPO Box \#90 - } \\
\text { Pakistan }\end{array}$ & 0092938310059 & 009293168643 & swws@brain.net.pk \\
\hline Swedish Committee for Afghanistan (SCA) & & 24-D, Chinar Road, UT, Peshawar, Pakistan & 009291840257 & & sca@brain.net.pk \\
\hline
\end{tabular}




\begin{tabular}{|c|c|c|c|c|c|}
\hline Terre des hommes & $\begin{array}{l}\text { Jean-Marie Dubey (Head } \\
\text { of Programmes Middle- } \\
\text { East and Eastern Europe) }\end{array}$ & $\begin{array}{l}\text { En Budron C8, } 1052 \text { Le Mont-sur-Lausanne, } \\
\text { Switzerland }\end{array}$ & 0041216546630 & 0041216546677 & jeanmarie.dubey@tdh.ch \\
\hline TDH Afghanistan - Delegation Office & Reinhard Fichtl & Street 5, Shar-I-Now, Kabul, Afghanistan & $\begin{array}{l}0093(0) 70 \\
277202 / 277225\end{array}$ & & tdhafghanistan@kbl.pactec.net \\
\hline $\begin{array}{l}\text { TDH Afghanistan - Peshawar Administration } \\
\text { Office }\end{array}$ & Reinhard Fichtl & $\begin{array}{l}\text { 3-C, Abdara Road, P.O. Box } 729 \text { UT, Peshawar, } \\
\text { Pakistan }\end{array}$ & $\begin{array}{l}009291 \\
5703814 / 852062\end{array}$ & & $\begin{array}{l}\text { tdhkabul@brain.net.pk } \\
\text { www.tdhafghanistan.org }\end{array}$ \\
\hline TDH Bangladesh & Laurent le Danois & $\begin{array}{l}774 \text { Satmasjid Road (1st Floor), Dhanmondi, } \\
\text { Dhaka 1209, Bangladesh }\end{array}$ & 008802811041 & 0088028113015 & tdh@bangla.net \\
\hline TDH Roumanie & $\begin{array}{l}\text { Jean-Luc Imhof } \\
\text { (Regional Delegate Tdh - } \\
\text { Eastern Europe) }\end{array}$ & Str. Zece Mese No. 7, Bucarest, Romania & 004012123832 & 004012123832 & tdhroumanie@opensys.ro \\
\hline TDH Vietnam & Rico Jordi & $\begin{array}{l}\text { P.O. Box } 610 \text {, Central Post Office, Ho Chi Minh } \\
\text { City, Vietnam }\end{array}$ & 008488423405 & 008488462891 & rico@tdh.andi-net.com \\
\hline Terre des hommes - Germany & $\begin{array}{l}\text { Ute Sodemann (Head of } \\
\text { Programme Department) }\end{array}$ & P.O. Box 4126, 49031 Osnabrück, Germany & 00495417101150 & 0049541707233 & \\
\hline UNICEF Afghanistan & Niloufar Pourzand & $\begin{array}{l}\text { House } 112 \text {, Street } 37 \mathrm{~F} 10 / 1, \text { Box } 3117, \\
\text { Islamabad, Pakistan }\end{array}$ & $\begin{array}{l}009251212948-51 / \\
281495 / 281508\end{array}$ & 009251212836 & npourzand@unicef.org \\
\hline UNICEF Peshawar & Umbreen Arif & $\begin{array}{l}\text { 78/60 Street No 6, Defense Officer Colony, GPO } \\
\text { Box 476, Peshawar, Pakistan }\end{array}$ & $\begin{array}{l}009291278524 / \\
279284\end{array}$ & 009291276952 & uarif@unicef.org.pk \\
\hline UNICEF Representative & Eric Laroche & $\begin{array}{l}\text { House \#112-3, Street 37, F-10/1, GPO Box 3117, } \\
\text { Islamabad, Pakistan }\end{array}$ & 0092512212948 & & elaroche@unicef.org \\
\hline
\end{tabular}

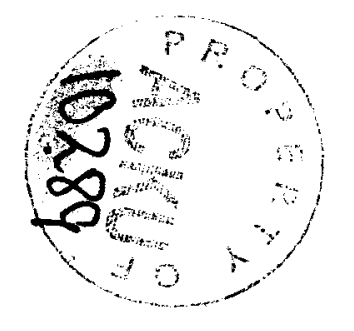

